\title{
Soberania Imperial, Espaços de Exceção - Campo de Guantánamo. Desterritorialização e Confinamento na "Guerra contra o Terror
}

\section{José María Gómez**}

Os Estados Unidos estão comprometidos com a eliminação mundial da tortura e lideram essa luta com o exemplo.

(Presidente G. W. Bush, junho de 2003)

Não sou advogado. Não me ocupo de aspectos legais. (Donald Rumsfeld, secretário de Defesa dos EUA, fevereiro de 2002)

Meu país [Mauritânia], esquivando-se do devido processo legal, entregou-me como um caramelo aos Estados Unidos. Me enviaram à Jordânia para a tortura, em seguida a Bagran [base aérea estadunidense no

\footnotetext{
* Artigo recebido e aprovado para publicação em abril de 2008. Traduzido por Eduarda Passarelli Hamann-Nielebock.

** Doutor em Ciência Política pela Universidade de Louvain, professor do Instituto de Relações Internacionais da Pontifícia Universidade Católica do Rio de Janeiro (IRI/PUC-Rio) e professor adjunto da Escola de Serviço Social da Universidade Federal do Rio de Janeiro (ESS/UFRJ).
}

CONTEXTO INTERNACIONAL Rio de Janeiro, vol. 30, nº 2, maio/agosto 2008, p. 267-308. 
Afeganistão] e depois a este lugar [...]. Estou afastado do mundo há mais de quatro anos e não sei o que se passa fora daqui.

(Mohamedou Ould Salí, detento de Guantánamo, 13 de dezembro de 2005)

Onovo século inicia-se com o nome de Guantánamo convertido no símbolo mais emblemático de violações e desprezo ao regime internacional de direitos humanos e de direito humanitário construído nos últimos sessenta anos. Em sua origem, encontra-se a autoproclamada "guerra contra o terror", criada pelo governo dos Estados Unidos, junto a duas guerras reais contra Estados fracos e uma proliferação incessante de medidas e dispositivos de segurança, em resposta aos atentados terroristas de 11 de setembro de 2001. O fato fundamental é que, desde janeiro de 2002, 775 pessoas, de mais de trinta nacionalidades procedentes de cerca de dez países (Afeganistão, Bósnia-Herzegovina, Egito, Emirados Árabes Unidos, Gâmbia, Indonésia, Mauritânia, Paquistão, Tailândia e Zâmbia), permaneceram detidas na base militar estadunidense da Baía de Guantánamo, sem acusações formais, sem julgamento justo e sob condições cruéis e desumanas de confinamento. ${ }^{1}$

Diante da criação de uma escandalosa situação de ilegalidade, o governo Bush viu-se obrigado, desde o início, a desdobrar-se em esforços tendentes a justificar, dentro e fora do país, o não-cumprimento não apenas de seus próprios dispositivos constitucionais e legais em matéria de direitos fundamentais para prisioneiros estrangeiros, mas também da proteção consagrada pelo direito internacional dos direitos humanos e do direito humanitário com o qual os Estados Unidos da América (EUA) se comprometeram juridicamente (Pacto dos Direitos Civis e Políticos, Convenção contra a Tortura, Convenções de Genebra). Tal postura e a realidade das violações que foram sendo conhecidas desencadearam uma multiplicidade de denúncias, reprovações e campanhas internacionais em diversas partes do mundo a favor do fechamento de Guantánamo e do fim das detenções indefinidas, torturas e maus-tratos das pessoas ali detidas. O governo, que 


\section{Soberania Imperial, Espaços de Exceção e o}

está na defensiva, insinua o fechamento. Até agosto de 2007, mais de quatrocentas pessoas foram liberadas ou transferidas para 26 países diferentes, enquanto cerca de 350 continuam com a situação inalterada, salvo um único caso julgado, este ano, a partir dos procedimentos irregulares estabelecidos pelo Executivo. E nada parece indicar que, ainda que Guantánamo seja fechado, a luta antiterrorista em escala global promovida pelo governo estadunidense dispense lugares semelhantes e se submeta às normas do direito internacional.

O objetivo deste trabalho é discutir elementos de análise sobre a natureza, o significado e o alcance do campo de Guantánamo. Com esta finalidade, descreve-se a trajetória do fenômeno inserindo-o na dinâmica mais ampla da globalização militarizada em curso, cujo vetor e forma dominante passam pela estratégia imperial dos EUA pós-11 de setembro. Articulada de maneira íntima (embora não sem tensões e contradições) com a lógica expansiva e as conseqüências do capitalismo global, tal estratégia implica, entre outros traços distintivos, a legitimação de crescentes espaços de exceção, a guerra preventiva sem ameaça de ataque iminente e a ascensão do "inimigo absoluto" encarnado na figura desterritorializada do novo terrorista teológico-político. Temas que, por si só, revelam a qualquer observador atento da história política do século XX, por um lado, a inquietante atualidade do pensamento de Carl Schmitt; e, por outro, a pertinência de seu uso crítico no debate contemporâneo com a finalidade de identificar e combater os perigos e as urgências das tendências regressivas de uma ordem mundial caótica e em transição.

\section{A Vertiginosa Marcha da Ilegalidade e da Violência}

A transformação de uma base naval em campo de concentração de prisioneiros provenientes de numerosos países e regiões do planeta foi o resultado de um conjunto de concepções, decisões e dispositivos colocados em prática pela Casa Branca e pelo Pentágono após os 
atentados terroristas de Nova Iorque e Washington. A história de sua implementação e posterior manutenção demonstra uma trajetória que se pode dividir em duas grandes fases de sentidos contrastantes. A primeira estende-se até meados de 2004 e caracteriza-se pelo impulso avassalador das iniciativas da administração Bush concentrando poderes discricionários e de emergência. A segunda projeta-se até o presente e revela os recuos do governo, com obstáculos e oposições de toda espécie (denúncias e pressões dos organismos de direitos humanos; certos freios institucionais domésticos da Suprema Corte e do Congresso; greves de fome e tentativas de suicídio coletivo por parte dos detentos; repúdio de organismos internacionais, de chefes de Estados e até dos ex-presidentes Carter e Clinton etc.), levando-o a declarar, recentemente, sua intenção de fechar o campo em um futuro próximo. Não obstante, Guantánamo persiste com toda a ilegalidade e violência que o constituem, apesar do desejo das autoridades de forjar uma cobertura legal e uma paródia de justiça. Uma breve descrição dos momentos e das medidas cruciais das fases assinaladas talvez permita compreender melhor a complexidade dos processos e as questões em jogo que fazem desse campo de concentração, verdadeiro gulag global, a ponta visível de um imenso iceberg, isto é, de uma rede inter e transcontinental, fluida e secreta de desaparecimentos forçados, prisões arbitrárias, traslados clandestinos de prisioneiros e torturas sistemáticas em prisões sob controle direto ou localizadas em terceiros países.

A escalada "decisionista" nas mãos exclusivas do Executivo começou em 14 de setembro de 2001, quando o país ainda estava em estado de choque, e o Congresso autorizou o presidente a usar a força contra aquelas "nações, organizações e pessoas" que, em sua opinião, tivessem qualquer relação com os ataques ao World Trade Center e ao Pentágono, ou com atos de terrorismo internacional que fossem cometidos no futuro. Quase um mês depois, ocorreu a invasão militar do Afeganistão liderada pelos Estados Unidos e apoiada por um am- 
plo arco de alianças - inclusive a Organização do Tratado do Atlântico Norte (OTAN) - com o objetivo imediato de derrubar o regime talibã e capturar os membros da Al Qaeda. Neste mesmo mês de outubro, o Senado aprovou o Patriot Act, que, além de suspender as restrições existentes à ação governamental com relação aos direitos civis, permitiu ao procurador-geral manter presos os estrangeiros suspeitos de atividades que pusessem em perigo a segurança nacional, com a obrigação, dentro do prazo de sete dias, de deportá-los ou de acusá-los de algum delito cometido. Porém, a peça-chave foi a ordem executiva assinada pelo presidente Bush em 13 de novembro de 2001 sobre "Detenção, tratamento e julgamento de certos estrangeiros na guerra contra o terrorismo". Com tal ordem, a partir de então, o Pentágono fica autorizado a manter cidadãos não nacionais sob custódia indefinida e sem encargos; proíbe-se que os detentos interponham qualquer recurso perante tribunais estadunidenses, estrangeiros ou internacionais; e afirma-se que, em caso de serem julgados, o julgamento realizar-se-á no âmbito das comissões militares nomeadas pelo Executivo (e não por tribunais independentes e imparciais), o que não se utilizava desde a Segunda Guerra Mundial. A partir dessa ordem, várias regulamentações administrativas do Departamento de Defesa são autorizadas com o propósito de esclarecê-la e torná-la mais efetiva. Por outro lado, no fim de dezembro do mesmo ano, em um memorando enviado pelo Departamento de Justiça ao Pentágono, recomenda-se que, pelo fato de a base naval da Baía de Guantánamo não ser território soberano estadunidense (de fato, é uma possessão militar dos EUA em território cubano desde 1902), os tribunais federais não sejam autorizados a examinar e julgar as petições de habeas corpus apresentadas por "estrangeiros inimigos" detidos em tal base.

Em janeiro de 2002, chegaram os primeiros prisioneiros provenientes do Afeganistão, detidos em jaulas metálicas na zona conhecida como Campo Raios X e, em seguida, transferidos para o Campo Del- 
ta. Neste mesmo mês, diante dos questionamentos que começavam a ser levantados sobre a legalidade nacional e internacional das medidas, o assessor da Casa Branca, Alberto Gonzáles, mais tarde promovido a fiscal geral (cargo que conservou até recente data, apesar da oposição à sua nomeação e permanência por parte dos democratas e dos organismos de direitos humanos), aconselhou o presidente a não aplicar as Convenções de Genebra no caso dos capturados no Afeganistão, de modo a impedir futuros processos das tropas e dos agentes de inteligência, em virtude da aplicação da Lei de Crimes de Guerra dos EUA, que incorpora e penaliza violações ao art. $3^{\underline{0}}$ comum das Convenções.

Duas semanas depois, em 7 de fevereiro, Bush assinou um memorando que estabelece que nenhum detento talibã ou membro da Al Qaeda será considerado prisioneiro de guerra e que, portanto, o referido art. $3^{\underline{0}}$ - exatamente aquele que garante normas mínimas para um julgamento justo e que proíbe a tortura, os maus-tratos e os atentados contra a dignidade dos prisioneiros, especialmente "os tratamentos humilhantes e degradantes" - não se aplicaria a eles. Assim, abria-se caminho para a noção de "combatente inimigo" e a suposta cobertura para as condições de detenção e técnicas de interrogatório "contraterroristas". Seis meses depois, em memorando de $1^{\underline{0}}$ de agosto dirigido a Alberto Gonzáles (que, por sua vez, reconhecia que o documento traduzia fielmente a postura da administração Bush), o procurador-geral adjunto do Departamento de Justiça afirmava que o presidente poderia invalidar a proibição da tortura (princípio que a Convenção específica de 1984 consagra de maneira absoluta e que os Estados Unidos ratificaram), pois seria possível causar dor intensa antes de ultrapassar a barreira da tortura e dispor de uma variada gama de técnicas de interrogatório que, ainda que pudessem ser equivalentes a tratamentos cruéis, humilhantes ou degradantes, não alcançariam o grau da tortura; e que, em última instância, se a utilização de tais métodos configurasse casos de tortura, "a necessidade de 
autodefesa poderia proporcionar as justificativas necessárias para eliminar toda a responsabilidade penal" dos agentes interrogadores fora dos Estados Unidos. ${ }^{2}$

Com o mesmo espírito, em dezembro de 2002, Donald Rumsfeld aprovava o uso discricionário de diversas técnicas de interrogatório, depois atenuado com a exigência de autorização em cada caso concreto. Não demorou muito para se divulgarem, por meio de organismos de direitos humanos, as técnicas que passaram a ser aplicadas em Guantánamo e em outros lugares (Bagran, Abu Ghraib e prisões secretas localizadas em países onde operavam os agentes da Central Intelligence Agency (CIA; em português, Agência Central de Inteligência). Entre tais técnicas, incluíam-se os atos de encapuzar e desnudar presos, isolamento prolongado, privação sensorial, permanência em posturas dolorosas, simulação de afogamento, utilização de cães para induzir o estresse etc., além de sistemáticas humilhações discriminatórias de caráter sexual e religioso. ${ }^{3}$ Em meio ao clima geral de múltiplas prisões e deportações arbitrárias de cidadãos estrangeiros, ${ }^{4}$ exaltação patriótica, cultura do medo, autocensura da mídia, restrição do debate público e estigmatização do dissidente que imperava na época (BUTLER, 2006), não chegava a surpreender que as justificativas da tortura transpassassem as instâncias oficiais e se instalassem nos grandes meios de comunicação, inclusive nos círculos acadêmicos. ${ }^{5}$ Além disso, não se pode perder de vista que tais representações, decisões e mecanismos, somados a outros de caráter mais amplo de espionagem, vigilância e controle (entre os quais cabe mencionar a recente lei que autoriza o monitoramento de chamadas telefônicas e correios eletrônicos de suspeitos sem autorização judicial; a criação do Departamento de Segurança Interna e da Information Awareness Office (IAO); a segunda versão da Lei Patriótica; os rígidos controles de fronteiras e a proteção da infra-estrutura mais importante, como portos, aeroportos, usinas nucleares etc.; e essa espécie de nova Lei Marcial Federal que é o John Warner National De- 
fense Authorization Act of 2007), fazem parte de um processo acentuado de concentração de poderes nas mãos da Presidência e de agências federais. Este processo é indissociável da implementação de uma estratégia unilateral e belicosa de reordenamento do sistema internacional, em nome dos imperativos de segurança da "nação em guerra". Trata-se de um processo cuja legitimação se reforçou ainda mais com a realização da anunciada guerra "preventiva" contra o Iraque, em março de 2003, e com a euforia inicial provocada pela rápida vitória militar que, segundo rezava a propaganda da época, pôs fim a uma ditadura sangrenta e implantou, de uma vez por todas no Oriente Médio, "a democracia, os direitos humanos e o livre-comércio" na força das armas. ${ }^{6}$

\section{Sobre Complicações Institucionais e Compromissos Perigosos}

Em meados de 2004, abre-se uma segunda fase carregada de dificuldades para o governo nos planos interno e externo. Em julho desse ano, o Pentágono anunciou a formação de Tribunais de Revisão do Estatuto de Combatente integrados por oficiais militares aos quais era permitido utilizar provas obtidas mediante coerção ou testemunho contra os detentos - que passariam, ou não, a ser classificados como "combatentes inimigos" -, mas os ventos políticos que circulavam já não eram tão favoráveis à Casa Branca. Sem dúvida, as imagens chocantes da prisão iraquiana de Abu Ghraib publicadas pela New Yorker e CBS News, as informações crescentes sobre o regime brutal ao qual eram submetidos os detentos em Guantánamo (ocasionando greves de fome e tentativas de suicídio) ${ }^{7}$ e as sentenças de tribunais civis com efeitos suspensivos das ações preliminares das comissões militares começaram a produzir impactos na opinião pública internacional e nacional, alimentando resistências institucionais e extra-institucionais domésticas, principalmente em um contexto de 
visível fracasso da ocupação militar no Iraque e da conseqüente perda de credibilidade do governo.

Depois do breve intervalo da reeleição de Bush, dois principais fatores precipitaram as iniciativas defensivas do governo com o objetivo de assegurar a descriminalização dos agentes de inteligência e de manter os dispositivos e as práticas repressivas vigentes fora do país. Por um lado, em novembro de 2005, uma investigação jornalística revelou que existia um número indeterminado de prisões clandestinas distribuídas em países aliados dos EUA, nas quais se praticava, sob o controle da CIA, todo tipo de tortura em suspeitos de terrorismo, assim como seqüestros, detenções ilegais e múltiplas transferências de prisioneiros em vôos secretos. As repercussões negativas da notícia foram imediatas na Europa, pois além de comprometer diretamente vários países europeus com prisões clandestinas (Romênia, Polônia), a notícia apontava para a conivência da maioria dos governos tanto em relação às detenções ilegais e "entregas extraordinárias" de suspeitos (Itália, Alemanha, Suécia, Holanda, Reino Unido), como em relação à autorização de mais de mil vôos secretos da CIA sobre seus respectivos espaços aéreos (GREY, 2005). ${ }^{8}$ Nos EUA, por sua vez, a notícia reforçava as pressões das organizações de direitos humanos na campanha pelo fechamento de Guantánamo e contra as violações dos direitos fundamentais e do Estado de Direito, inerentes à política de segurança implementada. Paralelamente, os agentes de inteligência, diante do crescente temor de serem processados por crimes de guerra, exigiam do governo uma cobertura legal robusta para prosseguirem com as "metodologias alternativas" de interrogatório - segundo o eufemismo presidencial utilizado para justificar sua eficácia e permanência -, até o momento em que o próprio Bush se viu forçado a reconhecer, em público e com atraso (em setembro de 2006), a existência de uma rede de prisões clandestinas e a transferência ("entregas extraordinárias") de quatorze detentos 
de "alto valor" dos chamados "buracos negros" (black sites) até Guantánamo. ${ }^{9}$

Por outro lado, os contrapesos institucionais começaram a funcionar na contramão das intenções governamentais. Primeiro, em dezembro de 2005, o Senado procurou proibir os tratamentos cruéis, desumanos e degradantes por meio do Detainee Treatment Act. Em seguida, em 29 de junho de 2006, a Suprema Corte impôs uma dura derrota ao Executivo ao decidir, no caso "Hamdan vs. Rumsfeld", que as comissões militares constituídas em virtude da ordem executiva de novembro de 2001 infringiam a legislação estadunidense e o direito internacional; neste sentido, declarava, contrariamente à resolução presidencial de fevereiro de 2002, que era aplicável o art. $3^{\underline{0}}$ comum das Convenções de Genebra. Diante de tais obstáculos institucionais, a Casa Branca viu-se impelida a articular no Congresso uma fórmula que revogasse o recurso de habeas corpus e legalizasse a continuidade não só dos "métodos alternativos" de interrogatório, mas também daqueles praticados no passado. Entretanto, as negociações mostraram-se mais difíceis do que a Casa Branca supunha: contar com a maioria republicana, sendo que as objeções levantadas ao projeto do governo têm origem justamente em senadores republicanos, em particular no senador John McCain, candidato presidencial, veterano da Guerra do Vietnã, vítima de torturas e opositor do uso de certas técnicas solicitadas pela administração e proibidas pelas Convenções de Genebra. O acordo final no Senado, em setembro de 2006, mais tarde aprovado pela Câmara dos Representantes, deixava exposta a marca ambivalente dos compromissos assumidos: enquanto se afastavam algumas das mais ultrajantes propostas da Casa Branca, aceitavam-se outras extremamente graves em matéria de garantias e proteção dos direitos humanos mais elementares. ${ }^{10}$ Assim, fruto dos acordos com o Senado, em 17 de outubro, Bush sancionou a Lei de Comissões Militares, que sistematizava as regras para perseguir, deter, interrogar e julgar suspeitos de terrorismo. Em seguida, 
na cerimônia da promulgação, não faltaram o discurso inflamado do presidente reafirmando a determinação da América de "ganhar a guerra contra o terrorismo" nem a justificativa de que, com a nova lei, abria-se "o caminho para aplicar a justiça aos terroristas que capturamos", salvar "vidas de estadunidenses" e relembrar as "vítimas do 11 de setembro". 11 Também era evidente a manobra do governo de explorar, mais uma vez, a funcional "guerra contra o terror" a apenas três semanas das eleições que renovariam o Congresso, em um clima político que lhe era desfavorável por causa da impopularidade da guerra no Iraque e dos sucessivos escândalos (sexuais e de corrupção) que afetavam a administração e os congressistas republicanos.

Porém, de fato e em sua essência, a nova lei tem pouca novidade. É certo que os senadores menosprezaram a demanda do Executivo de uma redefinição explícita dos padrões de tratamento contemplados pelo art. $3^{\underline{0}}$ comum das Convenções de Genebra, justificada como imprescindível para continuar com o programa de prisões secretas e com o próprio campo de Guantánamo. Ao mesmo tempo, entretanto, delegaram autoridade ao presidente para interpretar "o significado e a aplicação" de certas práticas humilhantes e degradantes relacionadas às proibições do mencionado artigo. Ainda que não tenha descriminalizado as mais abusivas técnicas de interrogatório utilizadas pela CIA - o que as torna, portanto, crimes de guerra passíveis de processo -, o texto denota um entendimento muito restrito sobre o que constituem tratamentos cruéis e desumanos, além de deixar sua interpretação nas mãos da administração. ${ }^{12} \mathrm{O}$ mais grave, contudo, é que não se reconhece aos detentos sob custódia dos Estados Unidos (em qualquer parte do mundo) o direito de recorrer a um tribunal de justiça independente para que este decida sobre a legalidade de sua detenção e tratamento, mesmo que tenham sido torturados e mesmo depois de serem liberados. ${ }^{13}$ Desse modo, "legaliza-se" a possibilidade de detenção indefinida, decidida em última instância por funcionários e agentes de inteligência, sem a exigência de acusação for- 
mal ou de julgamento justo. Mais de trezentas ações pendentes na Justiça - inclusive a que gerou a emblemática sentença da Suprema Corte em junho de 2006 - foram interrompidas, ao mesmo tempo que cerca de trezentos homens deverão permanecer indefinidamente no limbo infernal de Guantánamo, em flagrante violação das leis internacionais sobre conflitos armados. Já os que serão submetidos às novas comissões militares autorizadas pelo Congresso e estabelecidas pela ordem executiva da Presidência de 14 de fevereiro de 2007 (segundo fontes jornalísticas, os planos apontam para cerca de setenta prisioneiros) não poderão invocar as Convenções de Genebra contra o governo dos Estados Unidos por falta das mínimas condições exigidas para um julgamento justo, mesmo que eles venham a ser condenados e até executados sem as garantias elementares de defesa, a partir de confissões e provas obtidas por meios coercitivos e torturas anteriores à proibição do Senado de $2005 .{ }^{14} \mathrm{Nem}$ os próprios procedimentos militares das cortes marciais serão aplicáveis em tais comissões, reservando-se à Secretaria de Defesa o poder de ditar novas regras a respeito. ${ }^{15}$ Além disso, o texto legal amplia perigosamente a definição de "combatente inimigo ilegal", categoria criada para deixá-los fora da proteção das Convenções de Genebra, pois, em uma expansão sem precedentes da noção de combatente, incorporam-se aqueles que de maneira "deliberada e material" tenham apoiado hostilidades contra os EUA. Como a atribuição deste estatuto depende da avaliação dos corpos administrativos do Pentágono (os citados Tribunais de Revisão do Estatuto de Combatente ou qualquer outro tribunal estabelecido sob autoridade militar ou presidencial), fundamentando-se em provas secretas que o detento não conhece nem às quais tem acesso, há uma enorme margem de arbítrio, inatacável em virtude da inexistência de um mínimo de garantias de processo imparcial e da impossibilidade de revisão e controle judicial externo.

Mas se legalizar a situação existente para assegurar a impunidade e o segredo - daquilo que já foi feito e do que ainda se está por fazer - for 
a razão de ser da nova lei, isso não significa que os problemas que a tenham suscitado serão facilmente resolvidos. Basta lembrar que David Hicks, o único detento condenado até agora por uma comissão militar em março de 2007 (depois de cinco anos e dois meses de sua transferência a Guantánamo), declarou-se culpado em função de um acordo anterior ao julgamento e voltou ao seu país, Austrália, onde cumpre pena de nove meses. Outros dois detentos, o cidadão canadense Omar Ahmed Khadr e o iemenita Saim Ahmed Hamdan (que também haviam sido acusados pelas regras do sistema anterior), viram anuladas, em junho de 2007, por juízes militares, as acusações que pesavam sobre eles por não haver registro da declaração exigida de "combatentes inimigos ilegais". ${ }^{16}$ Para completar as dificuldades, a própria Suprema Corte declarou, em 29 de junho de 2007, que tratará e decidirá, não antes de 2008, a questão apresentada pelos detentos de Guantánamo e por diversos organismos de direitos humanos, de modo a averiguar se a Lei de Comissões Militares retirou dos tribunais federais a competência para examinar os recursos de habeas corpus, tal como insiste a Casa Branca. ${ }^{17}$ Tudo isso demonstra que o governo, debilitado pelas derrotas eleitorais legislativas internas e pelo pântano iraquiano no Oriente Médio, vê-se obrigado a fazer constantes alterações na implementação de uma legalidade mais que precária, viciada em relação aos parâmetros constitucionais e internacionais consagrados. Desse modo, à ampla lista dos que clamam pelo fechamento definitivo de Guantánamo foi incorporado até um íntimo colaborador da administração no mandato passado, o ex-secretário de Estado, Colin Powell, para afirmar sem rodeios que

[...] debilitamos a fé que tinha o mundo no sistema de justiça estadunidense, mantendo aberto um lugar como Guantánamo e criando entidades como as comissões militares. Não necessitamos delas, e já nos estão causando muito mais dano do que qualquer benefício que obtenhamos delas (AMNESTY INTERNATIONAL, $2007)^{18}$. Esta e as demais citações escritas origi- 
nalmente em língua estrangeira foram livremente traduzidas por nós para este artigo.

O próprio presidente Bush manifestou o desejo de que Guantánamo fosse fechado e de que alguns detentos "devessem ser julgados em tribunais aqui nos Estados Unidos" - na época, uma reunião na Casa Branca chegou a ser anunciada (e depois cancelada) para tratar do assunto (AMNESTY INTERNATIONAL, 2007). É provável, portanto, que se feche Guantánamo em um prazo não muito distante, pois o que mais interessa ao governo agora é, primeiramente, julgar uma minoria de reclusos segundo as regras atuais; limitar o máximo possível a revisão judicial das detenções; manter em segredo o sistema de "entregas extraordinárias" de prisioneiros; dar continuidade às prisões clandestinas e às técnicas de interrogatório utilizadas; e ir liberando o resto dos confinados (o que implica graves problemas de devolução aos países de origem, transferência a terceiros países e obrigações jurídicas de reparação). Em segundo lugar, conseguir, em um futuro próximo, apesar dos obstáculos crescentes, que uma legislação autorize detenções de longa duração e, de preferência, sem julgamento de presumidos terroristas estrangeiros dentro do próprio território dos EUA. Como deduziu o secretário de Defesa, Robert Gates, o desafio consiste em "encontrar uma base legal para a reclusão de presos que nunca devem ser colocados em liberdade e que podem ou não ser submetidos a julgamento" (AMNESTY INTERNATIONAL, 2007).

Em suma, ao negar as petições de habeas corpus aos cidadãos estrangeiros e consagrar a figura da "detenção indefinida"; ao definir de maneira ampla a noção insustentável, à luz do direito internacional contemporâneo, do "combatente inimigo ilegal"; ao implantar comissões militares que não contemplam as garantias de exercício do direito ao devido processo legal e de tantos outros que são violados; e ao reconhecer como genuínas e convincentes as provas obtidas por meio de técnicas proibidas de tortura, assim como restringir bastante 
a proteção contra maus-tratos e práticas humilhantes, a nova lei é a última expressão de uma ampla sucessão de decisões, dispositivos de segurança, concepções e práticas por meio dos quais os EUA assinalam para o resto do mundo que, em nome da luta contra o terrorismo, recusam-se a reconhecer qualquer limite espaço-temporal, político e jurídico que se apresente como obstáculo à sua ação e a seus objetivos. A franca resposta - com elevada dose de cinismo - do então secretário de Defesa, Donald Rumsfeld, à pergunta dos jornalistas sobre o estatuto jurídico dos primeiros prisioneiros de Guantánamo, diz tudo: "Não sou advogado. Não me ocupo de aspectos legais". Em outras palavras, proclama-se e leva-se adiante uma política antiterrorista de segurança que implica, necessariamente, a suspensão do Estado de Direito e um ataque direto aos fundamentos e à eficácia normativa do regime internacional de direitos humanos e do direito humanitário. Essas implicações, longe de serem um mero desvio ou anomalia selvagem de um grupo ideológico fanático que redefiniu de maneira súbita a política externa estadunidense, respondem, dentro das circunstâncias abertas pelo 11 de setembro, à natureza e às tendências contraditórias inseparáveis de um tipo de dominação imperial que, em um mesmo movimento, superdetermina e desestabiliza a ordem mundial que se pretende manter.

\section{Soberania Imperial, Situação de Exceção Mundial e "Inimigo Absoluto" Desterritorializado. 0 Retorno de Carl Schmitt}

Ao declarar a "guerra infinita" contra o terrorismo transnacional depois do sangrento ataque não convencional levado a cabo em seu território por um ator não estatal contra os símbolos máximos de seu poder financeiro e militar, os EUA desencadearam processos simultâ- 
neos e vinculados de fortalecimento dos poderes repressivos e de controle do Estado e de revisão profunda da ordem internacional pós-1945, da qual haviam sido arquitetos e protagonistas fundamentais. Passados seis anos, o panorama da política mundial não é, sem dúvida, dos mais animadores: unilateralismo belicoso de uma única superpotência infringindo o direito internacional e as instituições e práticas multilaterais, com perda de legitimidade hegemônica em vários lugares do planeta; ascensão vertiginosa da questão da segurança nas agendas nacionais, regionais e global; disseminação nas próprias democracias liberais de políticas "contraterroristas" que suspendem o Estado de Direito e reduzem certas pessoas a meros corpos sem direitos; expansão de redes de terrorismo islamita desterritorializado, tecnologizado e absolutizado em sua dimensão teológico-política; justificação da "guerra preventiva" como instrumento indispensável para enfrentar situações de "conflito assimétrico" e suprimir as ameaças de uso de armas de destruição em massa por parte dos "inimigos da humanidade" - terroristas islâmicos e Estados "párias"; deflagração de guerras de agressão entre Estados (em especial, as dos EUA contra o Afeganistão e o Iraque) e existência de conflitos armados e guerras civis em Estados fracos ou em colapso, com suas seqüelas de destruição, morte, ódio e desestabilização regional; tentativas de reconfiguração espacial do direito internacional, reeditando antigas dicotomias entre a força da lei para os "civilizados" e a força sem lei para os "bárbaros"; continuidade da globalização capitalista neoliberal, apesar da deslegitimação de suas conseqüências negativas (aumento da desigualdade dentro e entre países e regiões, mercantilização desenfreada em quase todas as esferas da vida, recorrentes turbulências e crises financeiras, intensificação da degradação ambiental etc.) e influência crescente de novos centros gravitacionais econômicos na Ásia; recrudescimento dos conflitos de caráter étnico, religioso e cultural junto à escalada do racismo; xenofobia; muros de separação; barreiras de entrada e discriminações a imigrantes, exilados e refugiados etc. 
Além da especificidade do contexto histórico e de algumas novidades que se apresentam, os aspectos salientados trazem de volta, nas palavras de Agamben (2002; 2004), o esquema clássico de reafirmação da soberania e de seu sujeito diante de uma situação de exceção. E com isso volta à tona a controversa obra de Carl Schmitt e sua definição de que "soberano é quem decide sobre o estado de exceção". Ou seja, quando a ordem e a segurança se vêem ameaçadas por um estado de necessidade extremo, "o soberano se coloca fora da ordem jurídica normalmente vigente, ainda que a ela pertença, pois é competente para decidir se a Constituição pode ser suspensa in toto" (SCHMITT, 2006, p. 7-8). ${ }^{19}$ A "pertinência inquietante" (SCHEUERMAN, 2006) deste pensador católico de direita radical, que aderiu ao nazismo e se manteve fiel ao longo de sua vida a posições antidemocráticas, antiliberais, anti-socialistas e anti-semitas, é dupla. Por um lado, no plano teórico, uma leitura crítica de suas ferramentas conceituais e esquemas de análise permite avançar na compreensão e interpretação de fatos e tendências dominantes do mundo político e jurídico contemporâneo, especialmente no período pós-11 de setembro, quando os EUA arrancam os "combatentes inimigos ilegais" da proteção do direito internacional e reforçam poderes discricionários e de emergência nas mãos do Executivo para determinar seu destino. Por outro lado, no plano político-ideológico, percebem-se "inspirações schmittianas" no círculo de colaboradores influentes, dentro e fora da administração Bush, comprometidos com a mudança da estratégia de segurança e da política externa de Washington, não como fruto do acaso, mas como uma convergência consciente de certas visões e argumentos. ${ }^{20}$

Na realidade, poucos textos de outras épocas se mostram tão esclarecedores - para não dizer quase proféticos - da situação atual como El nomos de la tierra (SCHMITT, 2001b, publicado originariamente em 1950) e El concepto de lo político/Teoria del partisano (SCHMITT, 1984, publicado originariamente em 1963), além dos que Schmitt dedicou durante as décadas de 1920 e 1930 à dupla 
conceitual soberania-exceção (La dictadura (SCHMITT, 2003), Teologia política (SCHMITT, 2006), Teoría de la Constitución (SCHMITT, 1996), e Legalidad y legitimidad (SCHMITT, 2001a)). Isso explica por que filósofos políticos europeus e escritores anglo-americanos (AGAMBEN, 2002; 2004; BALIBAR, 2001; 2005; DERRIDA，2005; 2007; HARDT; NEGRI，2000；2004; SCHEUERMAN, 2006), em um esforço de pensar o acontecimento, o que existe, busquem nas "perigosas" idéias desse autor, em companhia de outros pensadores nos quais também se inspiram (Benjamin, Foucault, Arendt), as chaves do entendimento do presente, não obviamente para legitimá-lo, mas para combatê-lo teórica e politicamente. ${ }^{21}$ Como não se interessar por um autor que, na conturbada primeira metade do século XX, abordou temas incandescentes de então, como os limites da revisão constitucional, formas de ditadura e de exceção, caráter espacial do direito internacional, despolitização e deslocamento da hostilidade política, ascensão inexorável do combatente irregular etc., quando o mundo de hoje assiste ao ressurgimento e à "banalização do estado de exceção" (AGAMBEN, 2002), que suspende direitos humanos consagrados nas Constituições e nos tratados internacionais diante das mais variadas "ameaças à segurança" - terrorismo, imigrantes clandestinos etc? Como não ver, nas análises paradoxais de Schmitt sobre a evolução do direito internacional europeu clássico e as transformações posteriores a 1945, as linhas de fuga pelas quais se filtra parte da enorme regressão que representam as atuais tentativas de reterritorialização do direito internacional, abrindo espaços e classificando sujeitos fora da proteção jurídica como "inimigos da humanidade" e "combatentes inimigos ilegais", localizados principalmente nos "Bálcãs globais" (BRZEZINSKI, 2005), e a quem se pode arbitrariamente confinar, torturar, fazer desaparecer e até matar com absoluta impunidade? Por fim, como ignorar as reflexões sobre o "partisano motorizado" e não meramente "telúrico" (territorializado) que se lança em um combate cuja causa e inimigo vão além de qualquer limite espacial e temporal e, ao mesmo tempo, confrontar-se com a evidência de uma 
Soberania Imperial, Espaços de Exceção e o Campo de Guantánamo....

nova versão de combatente "irregular" desterritorializado e em rede que, em guerra santa, pretende aniquilar o inimigo absoluto - EUA e seus aliados "infiéis" ou "traidores" - em qualquer lugar do mundo onde ele se encontre? ${ }^{22}$

Nos tópicos anteriores, descreveu-se como, depois dos atentados terroristas, avançou-se a passos largos e rápidos em direção a um estado de exceção não declarado mas efetivo, por meio de uma crescente concentração de poderes discricionários que o presidente estadunidense se atribuiu, em nome da Constituição, para atuar por cima dela e de seus mecanismos normais de controle, de modo a cumprir sua missão de "comandante-em-chefe" em tempos de guerra (SCHEUERMAN, 2006; GOLUB, 2006). Ao deter o monopólio da decisão e da ação política por meio do qual declara o "estado de urgência" da nação, define o novo inimigo e trava a "guerra permanente contra o terrorismo" em nome da defesa da América, o Executivo e, em seu ápice, o presidente, torna-se o soberano que exerce poderes ilimitados, com base em decisões secretas e medidas arbitrárias referentes ao uso da coerção e do controle estatal em questões cruciais (sequiestro, tortura, prisão secreta, operações ilegais de espionagem interna, sistema pseudojudicial paralelo sob domínio da Casa Branca e do Pentágono, guerra preventiva, desconhecimento de tratados internacionais etc.). A detenção "indefinida" de estrangeiros suspeitos de atividades terroristas é, sem dúvida, sua máxima expressão. Por meio dela,

[...] anula-se radicalmente todo estatuto jurídico do indivíduo, produzindo dessa forma um ser juridicamente inopinável e inclassificável. Os talibãs capturados no Afeganistão, além de não gozarem do estatuto de "prisioneiros de guerra" de acordo com as convenções de Genebra, também não gozam do estatuto de acusado segundo as leis norte-americanas. Nem prisioneiros, nem acusados, senão apenas detainees, são objeto de uma pura dominação de fato, de uma detenção indeterminada não apenas no 
sentido temporal, mas também com relação à própria natureza porque totalmente fora da lei e do controle judicial. A única comparação possível é com a situação jurídica dos judeus nos Lager nazistas: junto com a cidadania, haviam perdido toda identidade jurídica, embora pelo menos conservassem a identidade de judeu. Como Judith Butler claramente demonstrou, no detainee de Guantánamo a vida nua alcança sua máxima indeterminação (AGAMBEN, 2004, p. 14).

Diante das condições de "homo sacer", em que "todos os homens atuam como soberano" (AGAMBEN, 2002, p. 63), e do "[...] campo como o mais absoluto espaço biopolítico [...] no qual o poder não tem diante de si senão a pura vida sem qualquer mediação" (AGAMBEN, 2002, p. 178), fica evidente que o resultado não é outro senão o de seres humanos confinados na prisão da nova "guerra infinita", considerados ao mesmo tempo como não-humanos e "inimigos da humanidade". A detenção "indefinida", então, consiste em um mecanismo produtor de desumanização que, orientado por um marco racial-étnico identificador e diferenciador de certas populações (que mal dissimulam o velho ranço colonial e o legado do orientalismo ocidental), discrimina quem é humano e quem não é, quem merece viver e quem deve morrer, quem vai permanecer detido em razão de uma periculosidade inata e irrevogável (BUTLER, 2006). Um mecanismo, portanto, que funciona em um espaço sem lei, a não ser por aquelas ditadas pelo Executivo como sujeito do poder soberano do Estado de suspender a lei ou de fabricá-la em seu próprio benefício. Mesmo quando se trata, em última análise, de um poder soberano que termina por ser exercido por funcionários burocratas que decidem, com critérios incertos e sem nenhuma responsabilidade, se os detentos representam ou não um perigo para a segurança dos EUA (BUTLER, 2006). É por isso que a detenção indefinida se converte na figura condensadora e emblemática de uma política antiterrorista 
baseada na suspensão dos direitos fundamentais, na expansão das vigilâncias e controles e na contínua primazia do Executivo sobre o Legislativo e o Judiciário. Desse modo, manifestam-se uma prática e um ideário hegemônico que fomentam a "desconstitucionalização" e que se baseiam em uma grave ameaça que corrói por dentro a própria democracia liberal, o Estado de Direito e os direitos humanos como garantias de proteção perante o arbítrio estatal (BUTLER, 2006; ACKERMAN, 2006; GARAPON, 2006).

\section{Para além e depois de Guantánamo. Em Direção a uma Ordem e um Direito Internacional de Exceção?}

O ressurgimento do estado violento de soberania traduz-se pela pretensão de soberania universal por meio da qual os EUA se incluem e ao mesmo tempo se auto-excluem da implementação das novas regras constitutivas da ordem internacional em mutação que unilateralmente ditam e obrigam o respeito por todos os outros atores (BALIBAR, 2005). Tal pretensão assume várias formas que, diga-se de antemão, não derivam de uma súbita "ambição imperial" do governo e de sua política externa, mas sim da natureza imperial do poder global estadunidense e de suas transformações históricas ao longo dos últimos sessenta anos, desde o início de 1940, passando pela Guerra Fria e o fim dela, até a recente "guerra contra o terror" (COLAS; SAULL, 2006; COLAS, 2007; LAYNE, 2006). Sua forma mais evidente refere-se ao exercício do poder global de suspender a lei, os direitos e as instituições jurisdicionais internacionais, introduzindo a categoria de "combatente inimigo ilegal" e o castigo visível da detenção indefinida. Trata-se de uma novidade que só pode ser compreendida sob o pano de fundo de duas tendências históricas contrapostas que a trespassam. Uma, a mais antiga e em processo de dissolução, remonta à origem e consolidação do sistema interestatal 
europeu e à visão dominante dos direitos e da lei que rege com exclusividade a guerra convencional entre Estados reconhecidos, superando a guerra "santa" ou "justa" (as guerras civis confessionais) e substituindo-a pela dicotomia discriminadora entre o inimigo justo estatal - o justus hostil - e o inimigo injusto não estatal (pirata, fora-da-lei, criminoso etc.), desprovido de qualquer regulamentação legal. ${ }^{23}$ Outra tendência, mais recente e em ascensão, desenvolveu-se ao longo do século XX, sob os impactos das duas guerras mundiais, das guerras de descolonização e do papel crescente dos combatentes não estatais (partisanos). Ela consiste no esforço contínuo, embora carregado de inconsistências e fragilidades ainda não superadas, que tende a "regular, juridicamente, os combatentes irregulares” (SCHEUERMAN, 2006, p. 177).

A atual novidade estadunidense representa, portanto, um notável retrocesso à fase progressiva que experimentou o direito internacional dos direitos humanos e do direito humanitário nos últimos sessenta anos, caracterizado por estender o máximo possível, dentro de um sistema constituído por Estados formalmente soberanos, a proteção de todas as pessoas contra atos de barbárie, tal como proclama o Preâmbulo da Declaração Universal dos Direitos Humanos de 1948 (HELD, 2000; MONOD, 2007). A estratégia de segurança que o núcleo neoconservador busca estampar na política externa do governo Bush depois do 11 de setembro interrompe de maneira bruta essa tendência, reafirma a vontade de subtrair certa categoria de não-cidadãos estadunidenses da proteção da lei da guerra e dos direitos humanos e justifica a situação de exceção daqueles que deixa sob completa autoridade discricionária do Executivo e de suas agências especializadas no exercício do poder punitivo do Estado. Não surpreende, então, que "o argumento legal da administração Bush sobre o estatuto dos acusados de terrorismo reflita facetas cruciais da lógica de Carl Schmitt" (SCHEUERMAN, 2006, p. 118). No fim das contas, a convicção é a mesma sobre a impossibilidade e a indeseja- 
bilidade de uma codificação mais aprimorada das leis de guerra e dos direitos humanos que restrinjam o poder soberano. Com isso, reforça-se e aprofunda-se a linha seguida pelos EUA, ainda antes da virada estratégica de 2001 - incluindo Clinton -, de não aderir ou não fazer oposição ativa ao tratado que institui o Tribunal Penal Internacional, enquanto se negociam acordos bilaterais com diferentes países para assegurar a imunidade das tropas estadunidenses em caso de intervenções nos seus respectivos territórios. No entanto, essa linha ganhou um novo significado e alcance quando, diante da situação de exceção aberta pela "guerra infinita", é restabelecido o "tratamento irregular do radical irregular, ou seja, do terrorista" (MONOD, 2007, p. 171). Entre os vários efeitos perversos e paradoxais que isso gera, destaca-se o retorno de um tempo que já parecia ultrapassado, no qual prevalece de novo a noção de "guerra santa" e de "inimigo absoluto" a ser eliminado, em uma "afinidade elegida" com o tipo de crença e prática do terrorismo islamita transnacional. Daí as relações especulativas entre terrorismo e contraterrorismo e a espiral de violência ilimitada que ambos mutuamente desencadeiam e reforçam. ${ }^{24}$

É claro que essa pretensão universal de soberania que aponta em direção a uma ordem e um direito internacional de exceção se articula intimamente com outras formas. Uma delas é a busca do controle pleno das Nações Unidas, instituição de vocação universal que, enfraquecida e desmoralizada, enfrenta a escolha trágica de se submeter à instrumentalização legitimadora da decisão estadunidense ou de manter certa independência sob o risco de se autocondenar - segundo as palavras premonitórias de Bush - à "irrelevância" histórica. Outra é a postura de indiferença ou desprezo absoluto diante da chamada opinião pública internacional, como ficou demonstrado nas várias manifestações e protestos de alcance global contra a ilegalidade, ilegitimidade e imoralidade da guerra anunciada contra o Iraque. Outra, ainda mais evidente, é a política monetária e financeira 
dos EUA, que, desde os anos 1970, desempenha um papel-chave no processo de globalização capitalista neoliberal (GOWAN, 2003; HARVEY, 2004; 2005). Mas não há dúvida de que, na base de todas essas formas de pretensão universal de soberania, encontra-se o "monopólio da violência" em escala mundial que os EUA reivindicam para si em termos de uma superioridade militar não apenas de fato (uma absoluta disparidade de orçamento e tecnologia, além de uma vasta rede planetária de bases, tropas e serviços de inteligência e vigilância) (JOHNSON, 2007a), mas também legítima, como se a sua própria força fosse de "outra" natureza, de uma natureza que, em última instância, não necessita de justificativa quando se decide utilizá-la (BALIBAR, 2005, p. 137). Isto está afirmado com todas as letras na Estratégia de Segurança Nacional de setembro de 2002, e reiterado na versão mais discreta de março de 2006, em função das circunstâncias cada vez mais adversas no Iraque ${ }^{25}$ (AGUIRRE, 2006). Neste documento, afirma-se, de maneira oficial, a supremacia militar permanente dos EUA. Esboçada no início da década de 1990 pelos círculos neoconversadores de assumida postura belicista, a doutrina adquire forma articulada no Projeto para o Novo Século Americano, em 2000, até ser plenamente assumida pelo governo Bush, aproveitando a oportunidade propícia criada pelo 11 de setembro (MANN, 2004; HARVEY, 2004; JOXE, 2004; O'LOUGHLIN, 2006). ${ }^{26} \mathrm{Em}$ nome do direito à autodefesa, proclama-se que os Estados Unidos poderão empreender "guerras preventivas" contra as maiores ameaças (a relação terrorismo, Estados "párias" e meios de destruição em massa) à sua segurança interna, aos seus interesses vitais e à ordem internacional. Trata-se de vencer sempre, seja qual for o tipo de ataque ou conflito armado, inimigo, lugar e tempo - presente ou futuro. Paralelamente, anuncia-se, em recado dirigido a eventuais potências rivais e aos próprios aliados tradicionais, a intenção de impedir que qualquer Estado pretenda igualar-se à força militar estadunidense. Desse modo, os EUA assumem de forma unilateral a segurança mundial e a defesa dos valores civilizatórios ameaçados pelos novos ini- 
migos, uma vez que se consideram os únicos com capacidade material e vontade política para fazê-lo (KAGAN, 2003). Ao afastar as restrições e os obstáculos à projeção hegemônica de seu poder global, passam por cima do direito internacional, das organizações internacionais e até das antigas e leais alianças militares atlânticas, afirmando com força a posição de soberano na ordem internacional, ou seja, daquele que é capaz de decidir sobre o estado de exceção em escala mundial. E é no exercício desse poder soberano imperial que o terrorista emerge como a "nova figura genérica do inimigo" (MONOD, 2007, p. 156), em torno do e contra o qual se pretende estruturar a ordem internacional, em uma época em que a "guerra contra o terrorismo" se converte na questão prioritária de segurança.

Transcorridos seis anos de tentativas de reordenamento mundial baseadas mais na força do que no consenso, constata-se o enorme fracasso da estratégia estadunidense em termos de efetiva garantia da segurança internacional e de aceitação pelo resto do mundo da "guerra contra o terrorismo" como um tema privilegiado das relações internacionais. Ao contrário dos objetivos traçados, a estratégia gerou, sobretudo no Oriente Médio e na Ásia Central, efeitos contraproducentes e catastróficos (caos, insurgência, conflitos armados político-religiosos, derrota militar, desestabilização regional, corrida armamentista e nuclear, recrudescimento do terrorismo transnacional, fortalecimento do Irã como potência regional etc.) que expressam e retroalimentam um gigantesco blowback às políticas desenvolvidas desde a Guerra Fria pelos Estados Unidos e pelas demais potências ocidentais (JOHNSON, 2007b). Por sua vez, resistências de índole diversa manifestam-se desde o início no seio dos países centrais e na semiperiferia e periferia do sistema capitalista mundial, com um acentuado antiamericanismo (GILL, 2005). As resistências e os protestos contra a invasão e ocupação militar do Iraque crescem, inclusive no âmbito doméstico dos Estados Unidos, ainda que inferiores aos da época da Guerra do Vietnã. Há que se adicionar um fenômeno de 
fundamental importância para o futuro da política externa dos EUA e da própria ordem mundial liberal: a crise profunda da coalizão conservadora que deu sustento ao atual governo (que remonta aos anos 1970, quando se aglutinou em torno do propósito de acabar com a "síndrome de Vietnã" e de restaurar a hegemonia declinante do poder global estadunidense) e a ruptura pública do consenso no interior do establishment de segurança nacional que define, desde a década de 1940, a grande estratégia de projeção imperial informal de "portas abertas e fronteiras fechadas" (de fomento a mercados capitalistas e Estados territorialmente soberanos) em direção à periferia pós-colonial, com consentimento quando possível, e à força quando necessário, sem que se vislumbre seu restabelecimento no curto prazo (COLAS; SAULL, 2006; GOLUB, 2007). ${ }^{27}$ Não se pode esquecer, por outro lado, as graves implicações da situação de exceção e da soberania imperial sobre a democracia, o Estado de Direito e o conjunto dos direitos humanos, como resultado da ascensão do paradigma preventivo de segurança e controle que contamina a política nacional e internacional e que, no dizer de Cole e Lobel (2007), "comprometeu nossos espíritos, fortaleceu nossos inimigos e nos deixou menos livres e seguros".

De todo modo, isso não significa que a ameaça do terrorismo islamita transnacional, profundamente reacionário e antidemocrático e de um antiimperialismo mais que duvidoso, não seja real nem gere impactos efetivos nas relações internacionais. O que se questiona é o uso de tal ameaça e a pretensão de que ela se converta no eixo central da política mundial, ao qual todos os outros problemas e desafios devam se subordinar. Nesta direção, também se revela a importância crescente que adquirem de novo a geopolítica, a persistência de antigas crises e lugares de tensão, a gravidade de outras questões pendentes - financeiras, ambientais, de desenvolvimento, desigualdade, pobreza etc. - da agenda política global e até a moderação relativa com que a própria política externa dos EUA parece se orientar na conjuntura atual 
(postura mais negociadora com a Coréia do Norte e, a princípio, com o Irã; convocatória de uma reunião internacional sobre a mudança climática; fomento da volta da Organização das Nações Unidas (ONU) ao Iraque; gestos de aproximação com países "emergentes" como Índia e Brasil; relação mais cuidadosa com os aliados europeus tradicionais etc.). ${ }^{28}$ Ainda assim, contestam-se os termos em que se define o problema multidimensional do terrorismo e sua proposta de solução. ${ }^{29}$ Afinal de contas, a condenação ética e política do terrorismo não é incompatível com a defesa de uma política antiterrorista, tanto no plano nacional como no internacional, mas à condição de que esta última se articule com outras políticas (econômicas, financeiras, sociais, tecnológicas, culturais) que apontem para as fontes originárias desse fenômeno político complexo e que, evidentemente, respeitem as normas internacionais de direitos humanos e de direito humanitário (ROGERS, 2008). Caso contrário, será imposta apenas a opção do excepcionalismo difuso que a "guerra contra o terror" e a figura indeterminada do terrorista como inimigo absoluto pretendem legitimar, correndo o risco anunciado, por um lado, do uso cada vez mais recorrente e explícito da violência imperial para manter a ordem capitalista-liberal global; e, por outro lado, da autodestruição progressiva da democracia política e do Estado de Direito nos lugares em que funcionam com um mínimo de legitimidade e eficácia. 


\section{José María Gómez}

\section{Notas}

1. Ver Amnesty International (2007). Cabe salientar que as dificuldades de acesso às fontes confiáveis de dados sobre Guantánamo levaram o autor deste artigo a privilegiar os numerosos relatórios e notícias específicas que, desde 2002, organizações não governamentais (ONGs) internacionais de direitos humanos, especialmente Amnesty International e Human Right Watch, dedicam ao tema e estão disponíveis nos respectivos sites: <http://web.anmesty.org > e $<$ http://www.hrw.org>.

2. Citado no relatório da Amnesty International (2006b).

3. Ver os relatórios da Amnesty International de 2005 e de Human Rights Watch de 2006, disponíveis nos sites indicados na nota 1 . Sobre o vínculo direto entre Guantánamo e Abu Ghraib, cabe destacar que as técnicas de interrogação contraterrorista utilizadas em Guantánamo se difundiram na prisão iraquiana, sendo o seu principal responsável o general Geoffrey D. Miller, antigo comandante do campo de Guantánamo (SCHEUERMAN, 2006, p. 120). Cabe também assinalar que onze militares estadunidenses de baixa graduação foram investigados pelos abusos cometidos em Abu Ghraib, porém o único oficial acusado foi absolvido pela corte marcial, segundo notícias da agência Reuters de 30 ago. 2007 (ver cronologia de Direitos Humanos do Radar do Sistema Internacional, disponível em: < http://www.rsi.cgee.org.br>). Ver também o relatório da Amnesty International (2006a) e o testemunho de detentos já liberados confirmando as técnicas e seqüelas de seu uso em Amnesty International (2006b). Além disso, o general Tauba, responsável pelas investigações de Abu Ghraib, em entrevista à New Yorker, acusou o alto comando do Pentágono de ordenar métodos de tortura aos presos desta prisão (EL GENERAL..., 2007). Com isso, são confirmadas as declarações do ex-general-de-brigada, Manis L. Karpinski (encarregado da mesma prisão quando estourou o escândalo das fotos), dadas meses antes, de que Rumsfeld autorizara o emprego de torturas no Iraque e de que o general Miller enviara interrogadores "privados", com vasta experiência no Afeganistão e em Guantánamo, para participar dos interrogatórios (RUMSFELD..., 2006).

4. Como resultado imediato da aplicação do "paradigma de prevenção" antiterrorista doméstico, o governo Bush convocou cerca de 80 mil estrangeiros nacionalizados para inscrição em um "registro especial" simplesmente porque eram, em sua grande maioria, originários de países árabes e muçulmanos, enquanto 8 mil homens jovens destes mesmos países passaram a ser entrevistados pelo Federal Bureau of Investigation (FBI). Por outro lado, mais de 5 mil estrangeiros nacionalizados foram submetidos à detenção preventiva, sem que a 


\section{Soberania Imperial, Espaços de Exceção e o Campo de Guantánamo....}

algum deles fosse imputado algum crime terrorista, pelo menos não até setembro de 2007 (COLE; LOBEL, 2007).

5. Sobre a tortura e as tentativas de redefini-la para justificar a autorização de técnicas de interrogação "que salvariam muitas vidas", envolvendo os mais altos assessores legais da Secretaria de Justiça, do Pentágono e da Casa Branca (entre eles, Jay S. Bybee e Alberto Gonzáles), ver Scheuerman (2006). Sobre o alcance da justificação da tortura, inclusive nos meios acadêmicos, ver Aguirre (2005) e Ascherson (2006). Sobre as crescentes restrições ao uso da tortura no âmbito militar, porque seria desnecessária e contraproducente, em contraste com a posição dos serviços de inteligência, em particular da CIA, ver Huq (2007).

6. Foi em junho de 2003 que o Pentágono anunciou que o presidente Bush havia resolvido que seis detentos de Guantánamo reuniam os requisitos para serem julgados por comissões militares.

7. Ver os relatórios da Amnesty International de 2005 e da Human Rights Watch de 2006, já assinalados na nota 3. Há informações recebidas sobre mais de quarenta tentativas de suicídio; em junho de 2006, morreram três homens em Guantánamo, vítimas, ao que parece, de suicídios. Além disso, cerca de duzentos detentos fizeram greves de fome para protestar contra as condições de detenção (AMNESTY INTERNATIONAL, 2006c).

8. Ver o relatório do Comitê Temporário do Parlamento Europeu sobre abusos da CIA no território da União Européia, disponível no site da Human Rights Watch (<http://www.hrw.org >), com data de 29 nov. 2006. Segundo notícias publicadas no jornal Der Spiegel (TRATAMENTO..., 2007), cerca de quatrocentos vôos da CIA violaram o espaço aéreo alemão, tendo sido identificados como vôos de resgate (ou seja, livres da administração do fluxo de tráfego aéreo), com a finalidade de evitar as complicadas regulamentações de aprovação e a declaração explícita de objetivos (ou seja, seqüestro ou "guerra contra o terror").

9. Segundo informações disponíveis no site da Human Rights Watch $(<\mathrm{http}: / /$ www.hrw.org>), com data de 6 set. 2006. Ver também Amnesty International (2006d).

10. Ver as informações disponíveis no site da Human Rights Watch (<http://www.hrw.org $>$ ), com data de 22 de setembro de 2006. Sobre as características gerais da lei, ver também, dessa mesma organização, Human Rights Watch (2006).

11. Reproduzido no The New York Times de 28 nov. 2006 (<http://www. nytimes.com/2006/10/28/Washington>). 
12. Em 20 de julho de 2007, o presidente Bush assinou um decreto que proíbe o tratamento cruel e desumano, incluindo a humilhação relacionada a crenças religiosas, durante a detenção e o interrogatório de suspeitos de terrorismo. Paralelamente às novas regras, a Casa Branca autorizou que a CIA retomasse os interrogatórios sobre esses mesmos suspeitos usando técnicas mais duras - vetadas aos militares - para obter informações, de acordo com a lista do Departamento de Justiça. Dois dias depois, o diretor da Inteligência Nacional, Michael McConnell, defendeu em entrevista à rede National Broadcasting Company (NBC) os métodos da CIA, que prefere não identificar, pois não constituem tortura nem causam danos permanentes aos indivíduos, embora reconheça que não gostaria que um cidadão estadunidense fosse submetido aos mesmos métodos (ver cronologia de Direitos Humanos do mês de julho do Radar do Sistema Internacional, disponível no site <http://www.rsi.cgee.org.br>).

13. Segundo Scott Shane, em notícia publicada pelo The New York Times (SHANE, 2006), a CIA comunicou a um tribunal federal que prisioneiros suspeitos de pertencer à $\mathrm{Al}$ Qaeda não estavam autorizados a relatar os "métodos alternativos de interrogação" a que haviam sido submetidos em prisões clandestinas de países estrangeiros ("CIA proíbe a torturados relatar sobre suas torturas”, reproduzido pela Folha de S. Paulo de 5 nov. 2006).

14. Uma situação que se revela ainda mais escandalosa quando se sabe que, segundo recente estudo da Seton Hall University School of Law sobre o perfil dos detentos (DENBEAUX; DENBEAUX, 2006), baseado nos dados fornecidos pelo próprio Pentágono, somente $8 \%$ dos prisioneiros de Guantánamo foram classificados como combatentes da Al Qaeda, sendo que 55\% não cometeram ato hostil algum contra as forças dos EUA e aliadas. Por sua vez, apenas 5\% foram capturados pelas tropas estadunidenses, enquanto $86 \%$ foram detidos pelo Paquistão e pela Aliança do Norte e entregues em custódia aos EUA em troca de grandes recompensas. Para refutar esse estudo, o Pentágono tornou público um relatório em que se revêem as provas contra 516 prisioneiros processados pelas comissões de Guantánamo entre 2004 e 2005. De acordo com tal documento, $73 \%$ dos presos constituem "uma ameaça comprovada", $6 \%$ nenhuma ameaça e o resto não passa de "potencial ameaça". O porta-voz do Pentágono também anunciou que os Tribunais de Revisão do Estatuto de Combatente, depois de um ano de funcionamento, declararam que alguns detentos eram “ex-combatentes inimigos" e que eles os enviaram de volta a seus países de origem (ver cronologia de Direitos Humanos do Radar do Sistema Internacional de 26 jul. 2007, disponível em: <http://www.rsi.cgee.org.br>).

15. Sobre a "imparcialidade" desse tipo de processo judicial, ver Monge (2007). 


\section{Soberania Imperial, Espaços de Exceção e o Campo de Guantánamo....}

16. Não deixam de ser reveladores os termos com que um dos juízes militares fundamenta a sua decisão: "Dado que o uso de tribunais militares para julgar civis não goza de favor, não pode ter sido a intenção do Congresso obter um resultado lógico, ainda que não intencional, de avalizar os argumentos e a posição do governo neste caso (caso de Omar Ahmed Khadr), isto é, que os militares podem capturar quem quiserem, acusá-lo, submetê-lo a julgamento perante uma Comissão Militar e, só então, depois que a Comissão já houver sido convocada, resolver a questão inicial da jurisdição conforme a Lei de Comissões Militares" (AMNESTY INTERNATIONAL, 2007). Cabe assinalar que, em resposta a essas decisões de juízes militares, o Pentágono criou um Tribunal de Revisão de Comissões Militares como primeira instância de apelações.

17. O autor gostaria de destacar que, durante o processo de revisão do texto e no momento em que começa em Guantánamo o primeiro julgamento de cinco suspeitos de organizar os atentados terroristas de 11 de setembro, sob regras pouco claras, confissões obtidas por meio de torturas oficialmente reconhecidas e a possibilidade de condenação à morte (GLABERSON, 2008), a Corte Suprema dos EUA acaba de restituir, no dia 12 de junho de 2008, em resolução tardia e não unânime, contra a política da Casa Branca, a identidade legal dos estrangeiros detidos nesse campo global de confinamento, com o conseguinte direito de apelar aos tribunais civis. Embora se trate de uma decisão transcendente, parece conveniente não alimentar expectativas exageradas sobre as conseqüências efetivas desta decisão judicial no plano da estratégia, dos dispositivos antiterroristas e da rede de prisões secretas da CIA ou de aliados operando em território estrangeiro (ESPINOSA, 2008; VITKINE, 2007). Contudo, os dias de prisão em Guantánamo estão contados, até mesmo porque os dois principais candidatos presidenciais, o republicano John McCain e o democrata Barack Obama, já enunciaram a promessa de campanha de fechá-la.

18. Esta e as demais citações de originais escritos em língua estrangeira foram livremente traduzidas por nós para este artigo.

19. Segundo Schmitt (2006, p. 14): "o estado de exceção revela o mais claramente possível a essência da autoridade estatal", sendo que "a exceção [...] é mais interessante que o caso normal. O que é normal nada prova, a exceção comprova tudo; ela não somente confirma a regra, mas esta vive da exceção" (SCHMITT, 2006, p. 15).

20. Sobre a possível inspiração schmittiana da legislação antiterrorista e dos poderes excepcionais do presidente como chefe das Forças Armadas por parte de assessores jurídicos da Casa Branca, ver Scheuerman (2006) e Monod (2007). De todo modo, é preciso destacar o papel desempenhado por dois precedentes jurídicos na suspensão atual das garantias constitucionais em nome da "guerra contra o terror": The Enemy Alien Act, de 1798, que outorgava ao pre- 
sidente o poder de deter sem autorização judicial todo "inimigo estrangeiro"; e a noção de "poderes do Executivo em tempos de guerra" utilizada pelo governo Roosevelt para internar em campos de concentração cerca de 40 mil japoneses e 70 mil estadunidenses descendentes de japoneses (MONOD, 2007).

21. Para uma análise crítica do poder em termos da problemática soberania-exceção, incorporando, junto com Schmitt, as contribuições de outros pensadores contemporâneos - como Benjamin, Arendt e, em particular, os escritos de Michel Foucault $(2005 ;$; 2006; 2007) sobre biopolítica e as inter-relações entre soberania, disciplina e governamentalidade, ver Agamben (2002), Butler (2006) e Esposito (2005; 2006). Sobre a redescoberta recente de Carl Schmitt no campo das Relações Internacionais, ver Odysseos e Petito (2007).

22. Para uma avaliação do legado e da atualidade do pensamento de Schmitt na situação histórica presente, ver Monod (2007), Balakrishnan (2006) e Odysseos e Petito (2007) .

23. Cabe ressaltar que Schmitt atribuía a desestabilização do direito internacional clássico, baseado no princípio da soberania, ao perigoso retorno da guerra justa (que compromete a limitação espacial da guerra entre os Estados e a criminalização absoluta do adversário) levado a cabo pelo internacionalismo liberal, em nome da humanidade e do direito. E como a noção de humanidade exclui a de inimigo - essência do conceito do político, segundo seu ponto de vista -, “quem fala em humanidade, quer enganar" (SCHMITT, 1984, p. 51). Ou seja, é "um instrumento idôneo para as expansões imperialistas e é, também, na sua forma ético-humanitária, um veículo específico do imperialismo econômico". Além disso, pode expressar "a terrível pretensão de que ao inimigo lhe seja negada a qualidade de humano, de que se o declare hors-la-loi e hors l'humanité e, portanto, de que a guerra seja levada até o extremo da inumanidade" (SCHMITT, 1984, p. 51). É evidente que a defesa de Schmitt do Jus Gentium Europaeum como conjunto de regras sobre exércitos, prisioneiros e populações civis ditadas exclusivamente pelos e para os Estados europeus cristãos se refere à situação particular que atravessava a Alemanha após a Primeira Guerra Mundial e ao crescente poder dos EUA no sistema internacional. Trata-se de uma visão do mundo que, fora do centro civilizado, concebe as periferias como espaços a conquistar e a submeter às potências européias em competição selvagem em que, por definição, tais regras perderam a validade. Para uma leitura crítica do universalismo europeu como retórica da dominação sobre a periferia do sistema mundial desde o século XVI até o presente, ver o recente ensaio de Immanuel Wallerstein (2007). Para crítica ao uso atual das intervenções humanitárias e da justiça internacional no quadro da dinâmica de poder imperial global, em que a humanidade e a justiça estão sempre do lado do vencedor, ver Zolo (2007). 


\section{Soberania Imperial, Espaços de Exceção e o Campo de Guantánamo....}

24. Para uma renovada defesa da "guerra sem lei" ou da "lei da selva" contra os novos "bárbaros" (representados basicamente pelo terrorismo internacional, pelos Estados "párias" e pelos Estados falidos) que permite aos Estados Unidos irem "beyond the line" da civilização com o objetivo de manter a ordem capitalista liberal mundial, ver Kagan (2003) e Cooper (2003). Para crítica a estas posições, ver Zolo (2007).

25. Ver The White House (2002; 2006). Sobre as mudanças discretas introduzidas na versão de março de 2006, ver Aguirre (2006).

26. Sobre a origem intelectual do neoconservadorismo, suas principais idéias-chave na política interna e externa durante a Guerra Fria, sua confluência com outras variantes da direita tradicional política, social e religiosa a partir dos anos 1970, assim como as transformações desencadeadas pelo contexto unipolar dos anos 1990, até alcançar uma influência determinante sob a Presidência de George W. Bush, ver Frachon e Vernet (2006). Como demonstra um neoconservador arrependido - ma non troppo -, até o fim da Guerra Fria, quatro grandes linhas comuns distinguiam o pensamento neoconservador de outros enfoques que prevaleciam na política externa dos EUA (realistas, internacionalistas liberais, nacionalistas "jacksonianos"): a preocupação com a política interna dos Estados; a crença de que o poder estadunidense, sobretudo o militar, é com freqüência necessário para alcançar os fins morais universais; o ceticismo em relação à capacidade do direito e das instituições internacionais de resolver problemas sérios de segurança; e, por último, a visão de que os projetos ambiciosos de engenharia social e política costumam produzir consequiências imprevisíveis e indesejáveis (FUKUYAMA, 2006, p. 18). Com a envergadura das mudanças produzidas na política mundial entre 1989 e 1991, inicia-se um intenso debate interno sobre a natureza dos interesses dos EUA no mundo e sobre a necessidade de uma política externa adequada aos novos desafios e oportunidades de projeção de seu poder global, privilegiando como principais instrumentos para a promoção de um mundo "capitalista democrático" a esmagadora força militar de alta tecnologia e a mudança de regime naqueles Estados "párias" que resistirem em aderir consensualmente às normas liberais. E é desse debate que resultam as noções que, depois das eleições de 2000, passaram a ser a marca registrada do novo governo republicado (hegemonia benevolente, unilateralismo, mudança de regime, prevenção, afirmação da excepcionalidade virtuosa dos EUA) (FUKUYAMA, 2006, p. 18).

27. Embora estejam mais centradas nos erros de condução da invasão e da ocupação do Iraque do que na própria concepção estratégica que levou a essa guerra "opcional", as críticas que têm surgido nos diferentes setores do establishment de segurança (Forças Armadas, agências de inteligência, políticos, consultores acadêmicos) revelam não apenas a extensão das discordâncias, mas também a 
inevitabilidade de repensar a fundo as doutrinas de segurança e a estratégia geral que orienta a política externa dos EUA. Como afirmou diante do Comitê de Relações Exteriores do Senado, em fevereiro de 2008, o influente ex-membro do Conselho de Segurança Nacional, Zbigniew Brzezinski (apud GOLUB, 2007), a guerra do Iraque é uma “calamidade histórica, estratégica e moral”, que deixa "quase arruinado" o Exército e comprometida talvez de maneira irrecuperável "a legitimidade mundial da América". Não surpreende, portanto, que, diante da crise e da mudança de posições neoconservadoras, ecoem novamente os chamados realistas de prudência diante dos perigos das reações contra-hegemônicas no exercício do poder global, a recuperação do soft power e do jogo institucional-normativo dos internacionalistas liberais, ou as iniciativas a la Fukuyama (2006), com pretensão a um novo enfoque (denominado de "wilsonismo realista") combinando elementos neoconservadores, realistas e liberais.

28. O fracasso no Iraque da estratégia neoconservadora de assegurar a ordem mundial liberal mediante a colocação em prática de noções de "hegemonia benevolente", "guerra preventiva", "mudança de regime" e "excepcionalidade virtuosa" dos Estados Unidos forçou o governo Bush, nas atuais circunstâncias de enfraquecimento interno e forte desgaste da legitimidade hegemônica global, à adoção de um unilateralismo de perfil mais discreto e tom menos belicoso. Isso não implica, porém, em uma mudança substancial da política externa da hiperpotência, nem em um retorno ao status quo ante da virada "neocon" durante a Presidência de George W. Bush. Assim, tal como revelam os exemplos acima mencionados, com relação ao Irã, permanece aberta a possibilidade de lançar um ataque militar "preventivo", inclusive com a anuência de países europeus de peso (como a França de Sarkozy). Sobre a presença da ONU no Iraque, combina-se a busca da legitimação diante da aventura militar e política desastrosa com a recusa tanto da administração Bush como da oposição democrata em fixar um prazo para a retirada completa das tropas desse país. Sobre a iniciativa referente à mudança climática, não se esconde o objetivo de anular qualquer acordo geral que fixe prazos e metas de redução de emissão de gases que prejudiquem os países mais contaminadores, como parecia aspirar a conferência convocada pela ONU em Bali, em dezembro de 2007. Por fim, sobre a aproximação entre Índia e Brasil, o que se coloca em evidência é a maior "confiabilidade" desses países no jogo de interesses e alianças do poder global dos EUA para as próximas décadas, em comparação a outros "emergentes" menos "confiáveis" e mais imprevisíveis, como Paquistão, Arábia Saudita e Turquia (é evidente que não entram nesse cálculo a China e a Rússia, os mais sérios rivais estratégicos em potencial).

29. Cabe ressaltar que, depois dos atentados nos Estados Unidos e na Europa (Nova Iorque, Washington, Madri e Londres), passou a ocupar um lugar de destaque no debate político e acadêmico a questão da capacidade das democracias liberais de dar uma resposta adequada e eficaz às ameaças e aos perigos reais do 
terrorismo internacional. Trata-se de se afastar tanto das insuficiências de uma análise rígida da dicotomia exceção-Estado de Direito (o que não significa negar a permanência de zonas e sujeitos de exceção no seio de Estados de Direito consolidados, nem a crescente "banalização" da excepcionalidade para fazer frente às mais diversas ameaças - imigração, meio ambiente etc.), como da armadilha mortal que implica a resolução prática do dilema reducionista "liberdade versus segurança". No fim das contas, várias experiências históricas demonstram como esse dilema se baseia em um poderoso indutor, seja de aceitação de um regime de exceção - que é hoje o perigo maior -, seja de impotência de democracias indefesas - que, mais cedo ou mais tarde, acabam caindo também na "solução" anterior. Sobre essa discussão no plano jurídico, ver Ackerman (2006) e Garapon (2006). Para uma análise crítica dos dilemas contemporâneos entre liberdade e segurança, a partir de uma perspectiva transnacional, transdisciplinar e histórico-comparativa centrada na Europa, e privilegiando as políticas, significados e conseqüências do fortalecimento das exceções no quadro das democracias liberais, ver Bigo et al. (2006). 
ACKERMAN, Bruce. Les pouvoirs d'exception à l'âge du terrorisme. Esprit, Paris, n. 8-9, 2006.

AGAMBEN, Giorgio. Homo sacer. Belo Horizonte: Ed. UFMG, 2002.

. Estado de exceção. São Paulo: Ed. Boitempo, 2004.

AGUIRRE, Mariano. Exporting democracy, revising torture: the complex missions of Michael Ignatieff. Open Democracy, 15 jul. 2005. Disponível em: $<$ http://www.opendemocracy.net/democracy-americanpower/jefferson_ 2679.jsp>. Acesso em: ago. 2007.

Bush's security strategy: defend the nation, change the world. Open Democracy, 2006. Disponível em: <www.opendemocracy.net>. Acesso em: 31 jul. 2006.

AMNESTY INTERNATIONAL. Beyond Abu Ghraib: detention and torture in Irak. 2006a. Disponível em: <http://web.amnesty.org/library/eng-recent/index>. Acesso em: ago. 2007.

Guantánamo: Torturas y malos tratos. 2006b. Disponível em: <http://www.amnesty.org/library/print/ESLAMR511892006>. Acesso em: ago. 2007.

Cerremos Guantánamo. 2006c. Disponível em: <http://www.amnesty. org/library/print/ESLAMR511862006>. Acesso em: ago. 2007.

Guantánamo: la punta del iceberg de las entregas extraordinarias, la detención ilegal y los malos tratos en la "guerra contra el terror. 2006d. Disponível em: <http://amnesty.org/library/print/ESLAMR511902006>. Acesso em: ago. 2007.

. Renunciar a las comisiones militares, cerrar Guantánamo. 2007. Disponível em: <http://www.amnesty.org/library/print/ESLAMR511182007>. Acesso em: ago. 2007.

ASCHERSON, N. Torture: from regress to redress. Open Democracy, London, 2006. Disponível em: <www.opendemocracy.net>. Acesso em: ago. 2007. 


\section{Soberania Imperial, Espaços de Exceção e o Campo de Guantánamo....}

BALAKRISHNAN, Gopal. L'enemi. Un portrait intellectuel de Carl Schmitt. Paris: Éditions Amsterdam, 2006.

BALIBAR, Etienne. Nous, citoyens d'Europe? Les frontières, l'État, le peuple. Paris: La Découverte, 2001.

L'Europe, l'Amérique, la guerre. Réflexions sur la médiation européenne. Paris: La Découverte, 2005.

BIGO, Didier; WALKER, R. B. J.; chercheurs ELISE. Liberté et securité en Europe: enjeux contemporains. Cultures \& Conflits, n. 61, 2006. Disponível em: <http://www.conflits.org/index2040.html>. Acesso em: 12 ago. 2008.

BRZEZINSKI, Zbigniew. The choice. Global domination or global leadership? New York: Basic Books, 2005.

BUTLER, Judith. Vida precaria. El poder del duelo y la violencia. Buenos Aires: Paidós, 2006.

COLAS, Alejandro. Empire. Cambridge: Polity Press, 2007.

; SAULL, Richard (Ed.). The war on terrorism and the American “empire" after the Cold War. London, New York: Routledge, 2006.

COLE, David; LOBEL, Jules. Why we' re losing the war on terror. The Nation, New York, 24 sept. 2007. Disponível em: <www.thenation.com/doc/ 20070924/cole_lobel>. Acesso em: ago. 2007.

COOPER, Robert. The breaking of nations: order and chaos in the twenty-first century. New York: Palgrave, 2003.

DENBEAUX, Mark; DENBEAUX, Joshua. Report on Guantánamo detainees. New Jersey: Seton Hall University School of Law, 2006. Disponível em: <http:// law.shu.edu/news/guantanamo_third_report_7_11_06.pdf>. Acesso em: ago. 2007.

DERRIDA, Jacques. Canallas. Dos ensayos sobre la razón. Madrid: Editorial Trotta, 2005.

Força de lei. São Paulo: Martins Fontes, 2007.

EL GENERAL que investigó Abu Ghraib asegura que el Pentágono ordenaba las torturas en prisión. El País, Madrid, 19 jun. 2007. Disponível em: <http:/ /www.elpais.com/articulo/internacional/general/investigo/Abu/Graib/asegu- 
ra/Pentagono/ordenaba/torturas/prision/elpepuint/20070619elpepuint_6/Tes>. Acesso em: ago. 2007.

ESPINOSA, Angeles. 800 presos se hacinam en el "Guantánamo de Afganistán”. El País, 17 fev. 2008.

ESPOSITO, Roberto. Immunitas. Protección y negación de la vida. Buenos Aires: Amorrortu Editores, 2005.

Bíos. Biopolítica y filosofía. Buenos Aires: Amorrortu Editores, 2006.

FRACHON, Alain; VERNET, Daniel. La América mesiánica. Los orígenes del neoconservadurismo y las guerras del presente. Barcelona: Paidós, 2006.

FOUCAULT, Michel. Em defesa da sociedade. São Paulo: Martin Fontes, 2005.

. Seguridad, territorio, población. Buenos Aires: Fondo de Cultura Económica, 2006. ca, 2007.

. Nacimiento de la biopolítica. Buenos Aires: Fondo de Cultura Económi-

FUKUYAMA, Francis. O dilema americano. Democracia, poder e o legado do neoconservadorismo. Rio de Janeiro: Rocco, 2006.

GARAPON, A. Les dispositifs antiterrorists de la France et des États-Unis. Esprit, n. 8-9, 2006.

GILL, Stephen. Las contradicciones de la supremacía de Estados Unidos. In: PANITCH, Leo; LEYS, Colin (Ed.). El imperio recargado. Buenos Aires: CLACSO, 2005.

GLABERSON, William. Julgamento é tiro no escuro. O Globo, 6 jun. 2008.

GOLUB, Philip. États d'urgence permanent, Le Monde Diplomatique, sept. 2006. 2007.

. Traumatismos de fim de império. Le Monde Diplomatique-Brasil, out.

GOWAN, Peter. A roleta global. Rio de Janeiro: Record, 2003.

GREY, S. Comment les États-Unis inventent la délocalization de la torture. Le Monde Diplomatique, avril 2005. 
Soberania Imperial, Espaços de Exceção e o Campo de Guantánamo....

HARDT, Michael; NEGRI, Antonio. Empire. Paris: Exils, 2000.

Multitud. Guerra y democracia en la era del imperio. Buenos Aires: Debate, 2004.

HARVEY, David. O novo imperialismo. São Paulo: Editora Loyola, 2004.

A brief history of neoliberalism. Oxford: Oxford University Press, 2005.

HELD, David. Democracia y el orden global. Barcelona: Paidós, 2000.

HUMAN RIGHTS WATCH. Military Comissions Act of 2006. 18 oct. 2006. Disponível em: <http://wwww.hrw.org>. Acesso em: ago. 2007.

HUQ, Aziz. America's torture policy: past and future. 2007. Disponível em: <http://www.opendemocracy.net/node/33123/print>. Acesso em: ago. 2007.

JOHNSON, Chalmers. As aflições do império. Rio de Janeiro: Editora Record, 2007a.

Blowback. Os custos e as conseqüências do império americano. Rio de Janeiro: Editora Record, 2007b.

JOXE, Alain. El imperio del caos. Buenos Aires: Fondo de Cultura Econômica, 2004.

KAGAN, Robert. Do paraíso e do poder. Os Estados Unidos e a Europa na nova ordem mundial. Rio de Janeiro: Rocco, 2003.

LAYNE, Christopher. The peace of illusions: American grand strategy from 1940 to the present. Ithaca: Cornell University Press, 2006.

MANN, Michael. El imperio incoherente. Barcelona: Paidós, 2004.

MONGE, Y. Parodia judicial en Guantánamo. El País, Madrid, 21 out. 2007.

MONOD, Jean-Claude. Penser l'ennemi, affronter l'exception. Réflexions critiques sur l'actualité de Carl Schmitt. Paris: La Découverte, 2007.

ODYSSEOS, Louiza; PETITO, Fabio (Ed.).The international political thought of Carl Schmitt. Terror, liberal war and the crisis of global order. London: Routledge, 2007. 
O'LOUGHLIN, Ben. The intellectual antecedents of the Bush regime. In: COLÁS, Alejandro; SAULL, Richard (Ed.). The war on terrorism and the American "empire" after the Cold War. London, New York: Routledge. 2006.

ROGERS, Paul. Why we're losing the war on terror. Cambridge: Polity Press, 2008.

RUMSFELD autorizó las torturas en Irak, El País, Madrid, 25 nov. 2006. Disponível em: <http://www.elpais.com/articulo/internacional/Rumsfeld/autorizo/torturas/Irak/elpepiint/20061125elpepiintã7/Tes>. Acesso em: ago. 2007.

SHANE, Scott. CIA proíbe a torturados relatar sobre suas torturas. Folha de S. Paulo, Caderno Mundo, São Paulo, 5 nov. 2006. Disponível em: <http:// www1.folha.uol.com.br/fsp/mundo/ft0511200612.htm>. Acesso em: ago. 2007.

SCHEUERMAN, William E. Carl Schmitt and the road to Abu Ghraib. Constellations, Oxford, v. 13, n. 1, 2006.

SCHMITT, Carl. El concepto de lo político/Teoría del partisano. Buenos Aires: Folios Ediciones, 1984.

. Teoría de la Constitución. Madrid: Alianza Editorial, 1996.

.Legalidad y legitimidad. México: Fondo de Cultura Económica, 2001a. [Incorporado à seleção de textos de Héctor Orestes Aguilar - Carl Schmitt, teólogo de la política].

El nomos de la tierra. México: Fondo de Cultura Económica, 2001b. [Incorporado à seleção de textos de Héctor Orestes Aguilar - Carl Schmitt, teólogo de la política].

La dictadura: desde los comienzos del pensamiento. Madrid: Alianza Editorial, 2003.

Teologia política. Belo Horizonte: Del Rey, 2006.

THE WHITE HOUSE: The national security strategy. Washington D.C.: The White House, Sept. 2002. Disponível em: <http://www.whitehouse.gov/ nsc/nss.html>. Acesso em: ago. 2007. 


\section{Soberania Imperial, Espaços de Exceção e o Campo de Guantánamo....}

The national security strategy 2006. Washington D.C.: The White House, Mar. 2006. Disponível em: <http://www.whitehouse.gov/nsc/nss/2006/>. Acesso em: ago. 2007.

TRATAMENTO especial para o Tio Sam? UOL Mídia Global, 11 jul. 2007. Trad. George El Khouri Andolfato. Publicado originalmente em: GOETZ, John; ROSENBACH, Marcel; WASSERMANN, Andreas. Der Spiegel. Disponível em: <http://noticias.uol.com.br/midiaglobal/derspiegel/2007/07/11/ ult2682u511.jhtm>. Acesso em: ago. 2007.

VITKINE, Benoît. Um mergulho no coração das prisões secretas da CIA. Le Monde/Uol Mídia Global, 8 ago. 2007.

WALLERSTEIN, Immanuel. O universalismo europeu. A retórica do poder. São Paulo: Boitempo Editorial, 2007.

ZOLO, Danilo. La justicia de los vencedores. De Nuremberg a Bagdad. Barcelona: EDHASA, 2007.

\section{Resumo}

\section{Soberania Imperial, Espaços de Exceção e o Campo de Guantánamo. Desterritorialização e Confinamento na "Guerra contra o Terror"}

O objetivo deste trabalho é discutir elementos de análises sobre a natureza, o significado e o alcance do campo de concentração de Guantánamo. Com esta finalidade, descreve-se a trajetória do fenômeno, inserindo-o na dinâmica mais ampla da globalização militarizada em curso, cujo vetor e forma dominante passam pela estratégia imperial dos EUA pós-11 de setembro. Esta estratégia implica, entre outros traços distintivos, a legitimação de crescentes espaços de exceção, a guerra preventiva sem ameaça de ataque iminente e a ascensão do "inimigo absoluto" encarnado na figura desterritorializada do novo terrorista teológico-político.

Palavras-chave: Direitos Humanos - "Guerra contra o Terrorismo" Guantánamo - Estado de Exceção - Carl Schmitt 


\section{Abstract}

\section{Imperial Sovereignty, Space of Exception, and the Guantánamo Base. Deterritorialization and Confinement in the "War against Terror"}

The aim of this paper is to advance in the analysis about the nature, the meaning and the reach of the Guantánamo base. In order to do so, we describe the route of the phenomenon, integrating it in the broader dynamics of the current militarized globalization whose vector and dominating shape go through the imperial strategy of the USA post-September 11. Deep articulated with the enlarging logic and consequences of global capitalism, this strategy implies, among other distinctive traces, the legitimation of growing spaces of exceptions, the preventive war without imminent attack threat and the ascension of the "absolute enemy" embodied in the deterritorialized image of the new theological political terrorist.

Keywords: Human Rights - "War on Terrorism" - Guantánamo - State of Exception - Carl Schmitt 